\title{
Operational Risk of Insecurity using Control Self Risk Assessment and Linear Programming
}

\section{Ezekiel Awhigbo Bulus \& Monday Osagie *Adenomon}

Department of Statistics, Nasarawa State University, Keffi, Nigeria

*Corresponding Author: adenomonmo@nsuk.edu.ng ; +2347036990145

\begin{abstract}
This research work focused on the risks we are faced with on our day to day activities, either directly or indirectly, which can gradually accumulates and results to communal crisis, religious crisis, socio-economic agitations and tribal crises. Nasarawa Eggon Local Government Area of Nasarawa State was used as case study and a well structure close-ended questionnaire was used for data collection as it relates to Controlled Self Risk Assessment (CSRA) and linear programming technique was used to analyze. The results proved that many of this processes were neglected in these communities, making them to be prone to incessant communal crisis. The study recommend that Government should strongly, as a matter of urgency address the unemployment rate, distribution of political position, schools, primary health care and equip security personnel with the modern technology facilities, which happen to record the highest risk level.
\end{abstract}

Keywords: Risk, Security, Linear programming, Nasarawa Eggon and CSRA

\subsection{Introduction}

Insecurity has overwhelmed our homes, communities, local Government, states and up to the national level, through so many means of which some are known to us while some are not, these insecurities occur sometimes as a result of our carelessness, lack of discipline, refusal to accept 
and enforce the lay down laws that govern the people and poor knowledge concerning security. Jennifer et al (2007), describe the causes of insecurity to includes politics and elections, that is, the shift to democratic governance, the rise of armed groups, oil, ethnicity and religion, and poverty which are the major issues that represent dividing lines in communities that have led to heightened tensions between and within groups. But to say that groups or individuals are fighting over any single issue is too simple-minded. At the heart of many of these conflicts is access to resources and control over the distribution of benefits. This struggle for resources has led to a broad sense of opportunism, and the pursuit of self-help strategies across the country. Also according to Olabanji et al (2004) reveals that, an increase over time, which constitutes serious threat to lives and properties, hinders business activities and discourages local and foreign investors, all which stifles and retards Nigerian's socio-economic development. This rising wave of insecurity has not abated but has assumed a dangerous position which is threatening the corporate existence of the country as one geographical entity. In light of the aforementioned works, we found it necessary as residents of these areas to embark on this study as a prompt response to security challenges that have befallen our land in recent times. Jacob et al (2012) referred in fairness, that insecurity is not a problem that is unique to Nigeria but rather it has geographical spread across the globe. In addition, the United States, United Kingdom and many countries of the world faced similar challenges of insecurity within their borders on a daily basis. But the difference between these nations and Nigeria according to Adejumo (2011) is how they manage and responds to these threats. Unfortunately, the speed with which evil is growing in Nigeria and the merciless ways that lives of innocent ones are being wasted are worrisome. People are burdened on a daily basis with psychological and emotional trauma resulting from gory sights of lifeless and mutilated bodies of loved family member on daily basis. 
Previous studies such as Adeleke (2013) viewed insecurity as a hydra headed monster which security agents in Nigeria appear incapable of handling and said also that the power shift from the northern hegemony to a minority geo-political zone of South-south is currently on top in the list of issues that are instigating groups and individuals against the interests of the state. Other causes of insecurity challenges include intra/inter-party rancor; porous boundaries; unemployment, jobs racketeering and illiteracy. In view of these situations of insecurity in Nigeria, this study intended to use a risk management technique and mathematical model approach to come up with the possible means that can minimize some of these risks.

\subsection{Control Self Risk Assessment (CSRA)}

This is one of the tools that was develop by Gulf (1987) to evaluate control processes of the operational of staff, to pick out risk areas in a process, which is mostly used in our financial industries. CSRA is a process whereby risk inherent business unit's activities and associated controls are identified, subject to corrective action plan, appropriately documented and reported. A comprehensive Control Self Risk Assessment covers controls over the effectives of its process to ensure compliance with the applicable laws and regulations. It can be apply as tool in homes, communities, societies, and local government with special interest in Nasarawa Eggon local government area of Nasarawa State.

\subsection{Literature Review}

Eme et al (2011) study the Challenges of Insecurity in Nigeria in a thematic exposition, in their research they examine the concept of insecurity and its various manifestation using vital examples. It goes further to establish the need to check the rising threats to lives and property across Nigeria and the poor living conditions of many Nigerians. The work identifies the implications and challenges insecurity possess for the polity and concludes by positing that 
Nigeria's democracy is endangered as political intolerance, and economic frustration gather momentum in the form of assassinations, intimidations, threats and hostage across Nigeria. Jide et al (2012), examines that the Boko Haram's campaign targets security formations and churches in several parts of the North. Also, they have also turned their attacks on institutions like, the media and universities etc. From being an obscure movement confined to north-eastern Nigeria, the Boko Haram has emerged as the most palpable threat to the polity's continued peace and development. Not only do the persistent attacks of the sect create widespread insecurity and fear, the prevalent dread of the militant sect has stifled normal processes of trade and investments as well as the performance of routine security functions. and concludes by positing that for the terror to be won, the citizenry must see it as their fight and not just as an individual. Christina et al (2010) Study the overall rise in numbers of security incidents and the shifting of insecurity has been much discussed in the humanitarian literature. According to them 2006 report Providing Aid in Insecure Environments concluded that, 'the level of risk in highly insecure environments has been effectively transferred from $\mathrm{UN}$ agencies and international organizations to international NGOs, and from international NGOs to their national staff and local partners. Their report provides additional evidence by looking at patterns of security events from 1996 to 2010 that affected different types of humanitarian workers, categorized by origin, provider organization, and gender.

\subsection{Model formulation}

Suppose Nasarawa Eggon Local Government has seen the need to improve the security of lives and properties, however the number of process that will be used to pick out these risk will be, Satisfactory (L), Needing improvement and (M), and Unsatisfactory (H). Let $\mathrm{Lt}_{1}, \mathrm{Lt}_{2}, \ldots . . ., \mathrm{Ltk}$, be the number of Risk rated Satisfactory, $\mathrm{Mt}_{1}, \mathrm{Mt}_{2}, \ldots . ., \mathrm{Mt}_{\mathrm{k}}$, be the number of Risk Needing 
Improvement, and $\mathrm{Ht}_{1}, \mathrm{Ht}_{2}, \ldots \ldots, \mathrm{Ht}_{\mathrm{k}}$ be the number of Unsatisfactory Risk, in each community in Nasarawa Eggon Local Government. Suppose that (I) is the number of Inherent (I) Risk in the process tool and $(\mathrm{R})$ is the number of Residual $(\mathrm{R})$ Risks in the process tool in the community. Let $d_{1}, d_{2}, \ldots \ldots . ., d_{k}$, be the number of community whom will benefit from the Control Self Risk Assessment (CRSA) tool testing in the Local Government. The objective is to know the present value of Risk in each community in line with Korve et al. (1996).

\begin{tabular}{|c|c|c|}
\hline Process CRSA & Number Risk & Rate of Risk \\
\hline Satisfactory Risk & $\mathrm{Lt}_{1}, \mathrm{Lt}_{2}, \ldots \ldots, \mathrm{Lt}_{\mathrm{k}}$ & $\mathrm{L}$ \\
\hline Needing Improvement & $\mathrm{Mt}_{1}, \mathrm{Mt}_{2}, \ldots, \mathrm{Mt}_{\mathrm{k}}$ & $\mathrm{M}$ \\
\hline Unsatisfactory Risk & $\mathrm{Ht}_{1}, \mathrm{Ht}_{2}, \ldots \ldots, \mathrm{Ht}_{\mathrm{k}}$ & $\mathrm{H}$ \\
\hline Inherent Risk & $\mathrm{It}_{1}, \mathrm{It}_{2}, \ldots \ldots, \mathrm{It}_{\mathrm{k}}$ & $\mathrm{I}$ \\
\hline Residual Risk & $\mathrm{Rt}_{1}, \mathrm{Rt}_{2}, \ldots \ldots, \mathrm{Rt}_{\mathrm{k}}$ & $\mathrm{R}$ \\
\hline Community & $\mathrm{d}_{1}, \mathrm{~d}_{2}, \ldots \ldots, \mathrm{d}_{\mathrm{k}}$ & $\mathrm{D}$ \\
\hline
\end{tabular}

Let $\mathrm{X}_{1}, \mathrm{X}_{2}, \ldots \ldots \ldots, \mathrm{X}_{\mathrm{k}}$ the number of communities to be examined in the Nasarawa Eggon Local Government respectively, suppose that the government policy decision is specific to the minimum Risk they are to manage or bear, then the objective will check then the minimum value in each community and then compare it with the government minimum value. The linear programming problem is formulated in line with as

\section{Minimize}

$\sum_{j=0}^{k} \mathrm{di} \mathrm{Xj}$ 
$\sum_{j=i}^{k} \mathrm{Htj} \mathrm{Xj} \geq \mathrm{h}$

$\sum_{j=i}^{k} \operatorname{Mtj} \mathrm{Xj} \geq \mathrm{m}$

$\sum_{j=i}^{k} \operatorname{Ltj} \mathrm{Xj} \geq 1$

$\sum_{j=i}^{k} \mathrm{IjXj} \geq \mathrm{i}$

$\sum_{j=i}^{k} \mathrm{Rj} \mathrm{Xj} \geq \mathrm{r}$

For $\mathrm{j}=1,2,3$ $\ldots \mathrm{k}$

$0 \leq \mathrm{Xi} \leq 1$ for all h, $\mathrm{m}, \mathrm{l}, \mathrm{I}, \mathrm{r} \geq 0$

Where Htj, Mtj, Ltj, Itj, Rtj, are the number of satisfactory process, needing improvement process, Inherent Risk, Residual Risk, and h, m, 1, I, r is the number of Satisfactory process, Needing Improvement process, Inherent Risk, Residual Risk in the communities.

\subsection{Linear programming}

According to Business Dictionary, Linear programming is a mathematical techniques used in computer modeling to find the best possible solution in allocating limited resources (energy, machines, materials, money, personnel, space, time, etc) to achieve maximum profit or minimum cost. However, it is applicable where only all relationships are linear and can accommodate only a limited class of cost functions. For problem involving more complex functions, another technique called 'mixed integer modelling, is employed. Developed by the Russian Economist 
Leonid Kantorovich (1912-1986) and the U.S Economist C. Koopmans (1910-1986), on the basis of the work of the Russian Mathematician Andrew Nikolaevich Kolmogorov (1903-1987). According to the Wolframmathworld, Linear programming, is also knows as linear optimization, is the problem of maximizing or minimizing a linear function over a convex polyhedron specified by linear and non-negativity constraints. Simplistically, linear programming is an optimization of an outcome based on some set of constraints using a linear mathematical model. Linear programming is introduce in mathematics as linear programming, which find a vector $\mathbf{x}$ which minimizes a quantity cx subject to the constraints $m \mathbf{x}>b$ and $x_{i} \geq 0$ for $\mathrm{X}=\left(\mathrm{x}_{1}, \ldots, \mathrm{x}_{\mathrm{n}}\right)$.

Linear programming falls within convex optimization theory and is also consider to be an important of operational research. Linear programming is extensively used in business and economics, but may also be used to address some certain engineering problems.

Linear programming can be solved using the simplex method (wood and Dantzig 1949,) which runs along polytope ridges of the visualization solid to find the best answer, Khachian (1979) found a polynomial time algorithm. A much more polynomial time algorithm was found by Karmarkar (1984). This method goes through the middle of the solid (making it a so called interior point method), and then transfer warps. Arguably interior points method was knowing as early as (1960) in the form of the barrier functions methods, but the media hype accompanying Karmarkars announcement led to this method receiving a great deal of attention.

The origin of minimization problem is stated formally in a result of the von Neumann Duality principles, after the American mathematician John von Neumann (1903 - 1957).

$$
\begin{aligned}
& \mathrm{W}=\mathrm{c}_{1} \mathrm{X}_{1}+\mathrm{c}_{2} \mathrm{X}_{2} \ldots \ldots \ldots+\mathrm{c}_{\mathrm{n}} \mathrm{X}_{\mathrm{n}} \\
& \text { Subject to } \\
& a_{11} x_{1}+a_{12} x_{2}+\ldots \ldots \ldots \ldots+a_{1 n} x_{n} \geq b_{1} \\
& a_{21} x_{1}+a_{22} x_{2}+\ldots \ldots \ldots \ldots+a_{2 n} x_{n} \geq b_{2}
\end{aligned}
$$




$$
a_{m 1} x_{1}+a_{m 2} x_{2}+\ldots \ldots \ldots . . .+a_{m n} x_{n} \geq b_{m}
$$

Where $x_{i} \geq 0$ and $b_{i} \geq 0$ to solve this problem we solve the following steps:

1. Form the augment matrix for the given system of the inequalities and add a bottom row consisting of the coefficients of the objective functions

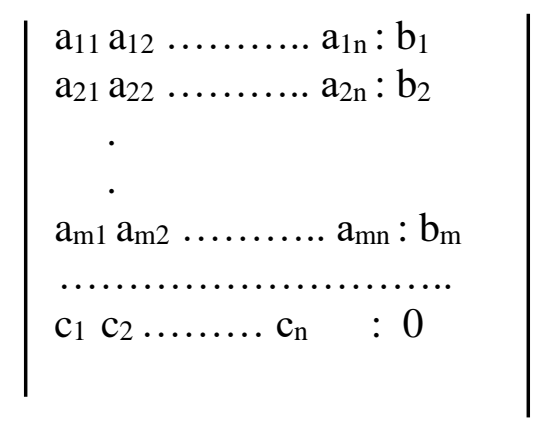

2. Form the transpose of the matrix.

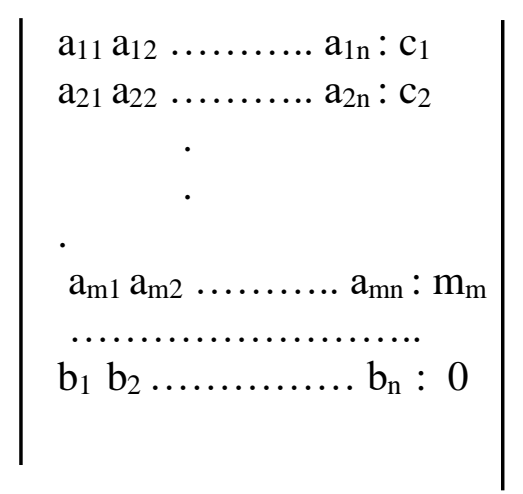

3. Form the Dual maximization problem corresponding to the transposed matrix.

That is, find the maximum of the objective function given by

$$
\mathrm{z}=\mathrm{b}_{1} \mathrm{y}_{1}+\mathrm{b}_{2} \mathrm{y}_{2}+\ldots \ldots \ldots+\mathrm{b}_{\mathrm{m}} \mathrm{y}_{\mathrm{m}}
$$

Subject to the constraints

$$
\begin{aligned}
& a_{11} y_{1}+a_{12} y_{2}+\ldots \ldots \ldots \ldots+a_{m 1} y_{m} \leq c_{1} \\
& a_{12} y_{1}+a_{22} y_{2}+\ldots \ldots \ldots \ldots+a_{m 2} y_{m} \leq c_{2}
\end{aligned}
$$




$$
a_{1 n} y 1+a_{2 n} y_{2}+\ldots \ldots \ldots+a_{m n} y_{m} \geq c_{n}
$$

where $\mathrm{y}_{1} \geq 0, \mathrm{y}_{2} \geq 0, \ldots \ldots \ldots \ldots$, and $\mathrm{y}_{\mathrm{m}} \geq 0$.

4 Apply the simplex method to the maximization problem. The maximum value of $\mathrm{z}$ will be the minimum value of $w$. Moreover, the values of $x_{1}, x_{2}, \ldots \ldots . ., x_{n}$ and will occur in the bottom row of the final simplex tableau, in the columns corresponding to the slack variables.

\subsection{Material and Method}

In this aspect of the study, the procedures for building the Control Self Risk Assessment model was discussed. An operational Risk model of insecurity in Nasarawa Eggon Local Government Using Control Self Risk Assessment (CSRA) and simplex method for minimization technique of linear programming case was developed as an extension of Korve et al (1996). The processes indices considered to be asses in the research work are Employment, Education, Laws, Police Station, Schools, Social amenity and infrastructure, Laws reform agencies, Primary health care clinic and Dialogue. A comprehensive Control Self Risk Assessment Process tool was formulated and was used to assess some few communities in the Nasarawa Eggon Local Government, and pick out those possible Risk areas that have trigger out the recent crisis in the local government and some part of the state.

The data was collected as follow: For the inherent Risk, that is, before accessing a particular index, from the outlook, structural appearance or hearing, one can record it to be either satisfactory, needing improvement or unsatisfactory, depending on how you see the appearance, thereafter, then you go in to access by asking question regarding the index, checking on the 
facility, equipment and interviewing the personnel working there to see whether the risk is also satisfactory, needing improvement or unsatisfactory. Thereafter you sum up the number of satisfactory, needing improvement and unsatisfactory risk before which is known as Inherent risk and also sum up the satisfactory, needing improvement and unsatisfactory risk after which is also known as Residual risks to form the matrices (details are presented in the appendix).

Table 1: Risk Assessment Form

\begin{tabular}{|c|c|c|c|c|c|c|c|}
\hline S/No & Process & \multicolumn{3}{|c|}{ Inherent Risks } & \multicolumn{3}{|c|}{ Residual Risk } \\
\hline & & $\begin{array}{c}\text { High } \\
\text { (H) }\end{array}$ & $\begin{array}{l}\text { Medium } \\
\text { (M) }\end{array}$ & $\begin{array}{l}\text { Low } \\
\text { (L) }\end{array}$ & $\begin{array}{l}\text { High } \\
\text { (H) }\end{array}$ & $\begin{array}{l}\text { Medium } \\
\text { (M) }\end{array}$ & $\begin{array}{l}\text { Low } \\
\text { (L) }\end{array}$ \\
\hline 1 & Employment & & & & & & \\
\hline 2 & Education & & & & & & \\
\hline 3 & Political position & & & & & & \\
\hline 4 & $\begin{array}{l}\text { Social Amenities and } \\
\text { infrastructure }\end{array}$ & & & & & & \\
\hline 5 & Police Station & & & & & & \\
\hline 6 & Law & & & & & & \\
\hline 7 & Dialogue & & & & & & \\
\hline 8 & Law reform agency & & & & & & \\
\hline 9 & Primary Health care & & & & & & \\
\hline 10 & Schools & & & & & & \\
\hline
\end{tabular}

\begin{tabular}{|c|c|c|}
\hline $\begin{array}{c}\text { Control self-Risk } \\
\text { Assessment } \\
\text { (CSRA) }\end{array}$ & $\begin{array}{c}\text { Risk before assessing the } \\
\text { community (Inherent) } \\
\mathrm{X}_{1}\end{array}$ & $\begin{array}{c}\text { Risk after assessing the } \\
\text { community (Residual) } \\
\mathrm{X}_{2}\end{array}$ \\
\hline $\begin{array}{c}\text { Number of high Risk } \\
\text { (Unsatisfactory Risk) }\end{array}$ & & \\
\hline $\begin{array}{c}\text { Number of medium } \\
\text { (Needing improvement) }\end{array}$ & & \\
\hline
\end{tabular}




\begin{tabular}{|c|l|l|}
\hline & & \\
\hline $\begin{array}{c}\text { Number of low Risk } \\
\text { (which is satisfactory) }\end{array}$ & & \\
\hline
\end{tabular}

An operational Risk model of insecurity in Nasarawa Eggon Local Government Using Control

Self Risk Assessment (CSRA) and simplex method for minimization technique of linear programming case was developed as an extension of Korve et al (1996).

\subsection{Discussion of Results}

In the Operational Risk Model, the Control Self Risk Assessment (CSRA) pick out those possible risk areas and formed a parameter in a form of a matrix, then the simplex method of linear programming technique was used to get the present minimum risk values in each community as recorded in the table 2 below and figure 1 below. in the case of Angbashuru Odne which recorded the highest risk value from the analysis correlate with the information recorded during accessing the community, the community was known to experienced consists violence and attack for quite a long period of time till the time of this research work alongside Mada station and others community with high level of tension that violence can escalate at any time. As earlier stated that this work became a necessity to check the risk level in this community through the indices mentioned above which actually shown that so many of these indices which is meant to keep and sustain rules and regulation among the people, were seriously neglected as they gradually wear out. This research work agreed with Jennifer et al (2007) whose stated in their work the major causes of insecurity that led to high tensioned in communities today are the rise of armed groups, ethnicity, religion, and poverty which can be liken to say, that the indices that should prevent this from existing or happening in our communities today were over looked and are out of hand, which we can vividly see this from the result of this work. In fact, we can 
boldly say that those rules and regulation they are merely songs in our mouth today but they are no longer in practice in our communities.

Table 2: The result value analysis of risk recorded during the research is as follow.

\begin{tabular}{|c|c|c|}
\hline $\mathrm{S} / \mathrm{No}$ & $\begin{array}{l}\text { Names of some community in Nasarawa Eggon } \\
\text { L.G.A }\end{array}$ & $\begin{array}{l}\text { Risk Recorded by Control } \\
\text { Self Risk Assessment }\end{array}$ \\
\hline 1 & Kuba Hamlet & 200 \\
\hline 2 & Nasarawa Eggon & 533.3 \\
\hline 3 & Wulko & 93.3 \\
\hline 4 & Alhamis Ezzen & 400 \\
\hline 5 & Kagbu Wane & 100 \\
\hline 6 & Mada Station & 625 \\
\hline 7 & Lizy Keffi & 450 \\
\hline 8 & Lambaga & 225 \\
\hline 9 & Angbashuru Oddne & 1500 \\
\hline
\end{tabular}

Source: Control Self Risk Assessment and Simplex Method technique 


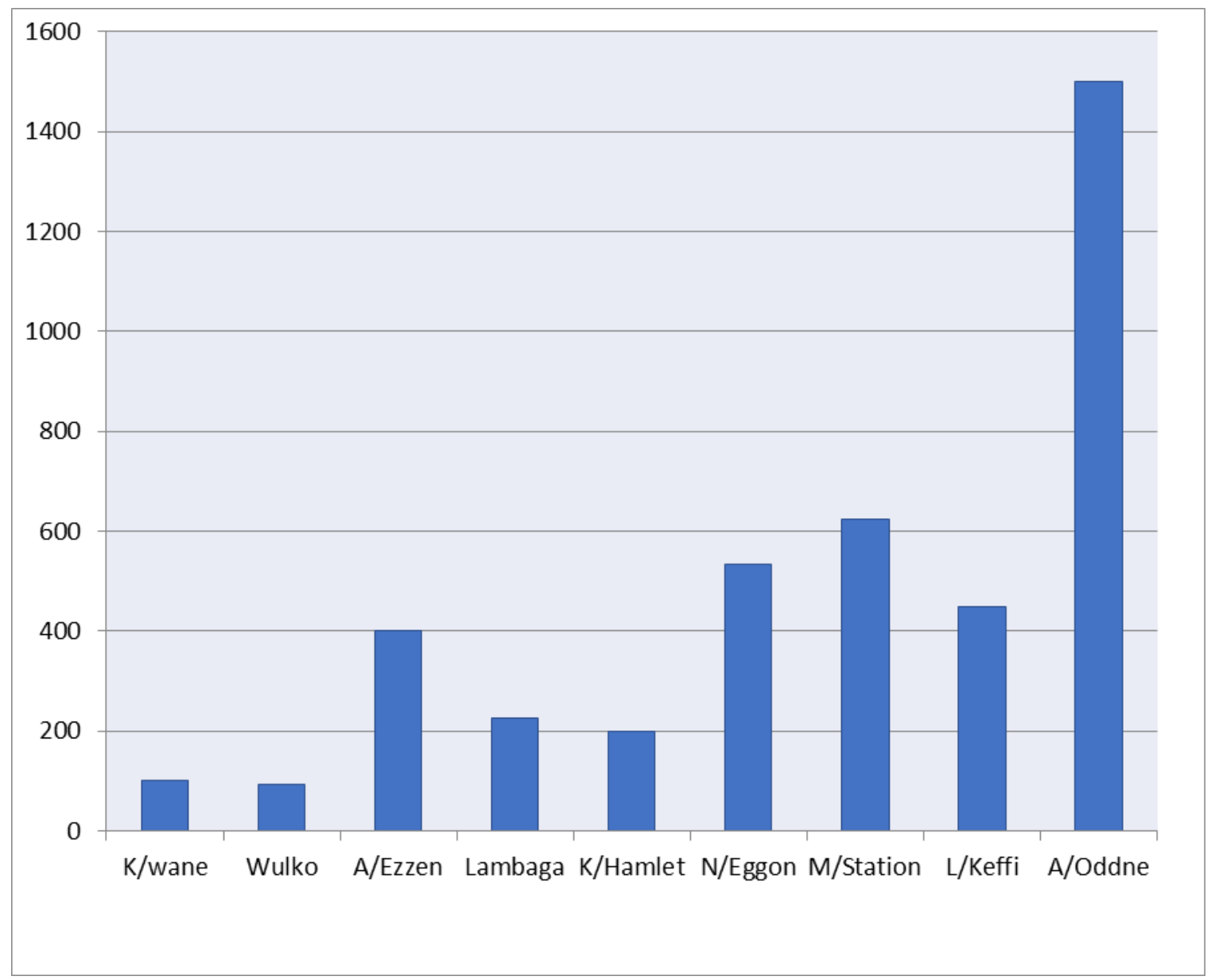

Fig 1: The Graphical Representation of the Risk value

\subsection{Conclusion and Recommendations}

This model was able to pick out those possible risk areas that causes the inter-tribal crisis, ethnoreligious crisis, socio-economic agitations, ethnic militias, boundary disputes, cultism and criminality also as a result hindering economic activities, tourism, and good democratic political system in some communities in the local government ranging from unemployment, Poor Educational system, Social amenity and Infrastructure, Lack of Police Station and scarcity of security personnel, Lack and Poor Primary Health Care Clinic, etc. The Model should be used as the name implies from one of it tools which is control self-risk assessment (CSRA) to assess 
each community to know the insecurity level, so that the policies maker, such as Government, Non-Governmental Organization etc should give attention to those communities that have more of security challenges in time of distribution of resources and allocation of budgetary.

In line with the results, The government should strongly address the unemployment, distribution of Political position, schools and primary health care issues which was noticed during the research work to have the highest risk record that contribute to insecurity in most of the communities. The Government, Non-Governmental organization (NGO) and other Civil Society Groups should consider using this models which is easier and less cause for the Operation. Also Government should focus, trace the possible risk areas and resources should be directed to places with high risk of insecurity.

\section{REFERENCES}

Adeleke A.(2013): Insecurity: A Threat to Human Existence and Economic Development in Nigeria. Public Policy and Administration Research, 3(6):1-6.

Adejumo, A.A. (2011). The problems and challenges of insecurity in Nigeria. Retrieved 22.07.2014 from http://newsdiaryonline.com/tok_security.htm

Agena, A. (2004): White Paper- intelligent solutions for quantifying Operational Risk Agena Ltd.

Andrew N. K. (1986): Probability theory. www.britannica.com

Bssel Committee on Banking Supervision (2003): The New Bassel Accord. BIS Bassel Switzerland.

Christina, W. \& Larissa, N. (2013): Operating in Insecurity Shifting patterns of violence against humanitarian aid providers and their staff (1996-2010). Insecurity Insight Report 13-19s

Eme, O. I \& Anthony, O. (2011): the challenges of insecurity in Nigeria, Interdisciplinary journal of contemporary research in business $3(8)$.

Eme, O. I. \& Jide, I (2012): The Cost of Boko Haram Activities in Nigeria. Arabian Journal of Business and Management Review 2(2)

Emmanuel, M. A. (2012); NEXIM Bank Risk Management NYSC Program Lectures 
Gulf C. (1987): https:/en.m.wikipedia.org/wiki/control_self-assessment.

Gyongyyer D. (2012): Socio-Economic Uncertainty and violent conflicts MICROCON John Von Neumann. (1950), Duality Theorem, University of Berlin.

Jacob, O. \& Andrew, A. O. (2015): Terrorism and Insecurity in Nigeria: Moral, Values and Religious Education as Panaceas. Journal of Education and Practice, 6(11): 1-8

Jennifer, M. H \& Jonas, H. (2007): Small Arms, Armed Violence and Insecurity in Nigeria: The Niger Delta in Perspective. Graduate Institute of International Studies, Geneva.

Khachaian G. (180): Linear Algorithms. Journalof Algorithms, 1(1): 1 -13

Leonid V. K. (1960): Mathematical Method of Organizing and Planning Production. Management Science 6(4): $366-422$.

Narendra K. (1984): A New Polynomial Time Algorithms for Linear Programming. Combinatorica, 4(4): 375 - 395

Olabanji, O.E \& Ese, U. (2014): Insecurity and Socio-Economic Development in Nigeria. Journal of Sustainable Development Studies. Journal of Sustainable Development Studies, 6(1): 40-63

Okoli, A. \& Atelhe, G. A. (2014): A Political Ecology of Herder/Farmer Conflicts in Nasarawa State, Nigeria. American International Journal of Contemporary Research 4(2).

Onifade, C. Imhonopi, D. \& Urim U M. (2013): Addressing the Insecurity Challenge in Nigeria and the Imperative of Moral Values and Virtue Ethics, Global Journals Inc (USA) paper 67.

Robert, B. (2007): National summit on Americas Silent Epidemics. Washington, DC.

Salau, E. S. \& Attah, A. J. (2012): A Socio-Economic Analysis of Urban Agriculture, American International Journal of Contemporary Research 1(1): 17-29

Tjalling K. (1986): Linear Regression Analysis of Economist Time Series. Wikipidia.

Umar, M. (2012): Lecture Note on Operational Research, Department of Mathematical sciences, Nasarawa State University Keffi, Nigeria.

Worlframmathworld: Linear Programming. mathworld.worframe.com/linearprogramming 


\section{APPENDIX}

\section{NASARAWA EGGON LOCAL GOVERNMENT AREA PROCESS FOR CONTROL SELF RISK} ASSESSMENT (CRSA)

\begin{tabular}{|c|c|c|c|c|c|c|}
\hline PROCESS & SUB PROCESS & RISK DISCRIPTION & $\begin{array}{l}\text { INHERENT } \\
\text { RISK H/M/L }\end{array}$ & $\begin{array}{l}\text { CONTROL } \\
\text { DISCRIPTION }\end{array}$ & TEST STEPS & $\begin{array}{l}\text { RESIDUA } \\
\text { RISK } \\
\text { H/M/L }\end{array}$ \\
\hline Employment & $\begin{array}{l}\text { Seventy five (75\%) } \\
\text { percent's of people } \\
\text { living here have to } \\
\text { be employed }\end{array}$ & $\begin{array}{l}\text { Unemployment usually } \\
\text { result to some form of } \\
\text { crime rate and violent } \\
\text { agitator, it's breed } \\
\text { discount against the state } \\
\text { and any incident may } \\
\text { trigger violent } \\
\text { demonstration and social } \\
\text { unrest which may result in } \\
\text { loss of life and property } \\
\text { also as a result of } \\
\text { unemployment social } \\
\text { security is jeopardize. It } \\
\text { also instigate electoral } \\
\text { violence and become } \\
\text { automatic threat to social, } \\
\text { economic and political } \\
\text { security. }\end{array}$ & & $\begin{array}{l}\text { Proper supervision and } \\
\text { adequate resources should } \\
\text { be invented to support } \\
\text { employment base across } \\
\text { the Area, and there should } \\
\text { be increase allocation of } \\
\text { national budget for } \\
\text { employment promotion } \\
\text { activities. } \\
\text { Government should } \\
\text { increase effort to facilitate } \\
\text { greater access of operators } \\
\text { in the formal sector to the } \\
\text { means of production } \\
\text { through land and improve } \\
\text { management technology. }\end{array}$ & $\begin{array}{l}\text { Verity that out of } \\
\text { hundred percent } \\
(100 \%) \text { of people in } \\
\text { each community how } \\
\text { many are workers. }\end{array}$ & \\
\hline Education & $\begin{array}{l}\text { There should be } \\
\text { primary and } \\
\text { secondary schools } \\
\text { in every } \\
\text { community in the } \\
\text { Area. We should } \\
\text { have literate people }\end{array}$ & $\begin{array}{l}\text { If people are not educated } \\
\text { it will serve as a barrier to } \\
\text { social development work } \\
\text { with individual and groups } \\
\text { in the community. It will } \\
\text { cause inability and } \\
\text { incapacity of individual }\end{array}$ & & $\begin{array}{l}\text { Adequate and conscious } \\
\text { effort should be made to } \\
\text { ensure improvement in the } \\
\text { education and training } \\
\text { provided to young people } \\
\text { with a greater focus on } \\
\text { vocational skills and }\end{array}$ & $\begin{array}{l}\text { Verify if the } \\
\text { communities have } \\
\text { primary and secondary } \\
\text { schools }\end{array}$ & \\
\hline
\end{tabular}




\begin{tabular}{|c|c|c|c|c|}
\hline & in each community. & $\begin{array}{l}\text { and group of all ages due } \\
\text { to their exposure. Their } \\
\text { action will not improve } \\
\text { their quality of life; central } \\
\text { to this is their inability to } \\
\text { participate in democratic } \\
\text { process. }\end{array}$ & $\begin{array}{l}\text { training. People should be } \\
\text { trained to acquire } \\
\text { transferrable high skills } \\
\text { highly meeting the current } \\
\text { economic trend. }\end{array}$ & \\
\hline $\begin{array}{l}\text { Primary Health } \\
\text { care clinic }\end{array}$ & $\begin{array}{l}\text { Each community } \\
\text { should be provided } \\
\text { with a well equip } \\
\text { clinic }\end{array}$ & $\begin{array}{l}\text { The absent of health care } \\
\text { or inadequate facility of } \\
\text { health in a community will } \\
\text { give access to different } \\
\text { kind of disease like the } \\
\text { polio, disability, Hepatitis } \\
\text { B.A and C, meningococcal } \\
\text { disease, invasive } \\
\text { pneumococcal infection, } \\
\text { which may lead to death } \\
\text { and also challenges in time } \\
\text { of birth delivery that also } \\
\text { result to loss of life and } \\
\text { will make people not to } \\
\text { have interest to any } \\
\text { democratic process due to } \\
\text { negligence of the } \\
\text { authority. }\end{array}$ & $\begin{array}{l}\text { A well equip structure } \\
\text { should be put in place. } \\
\text { Professional and expert } \\
\text { should be employ to } \\
\text { manage it, also } \\
\text { immunization should be } \\
\text { introduce against feature } \\
\text { disability }\end{array}$ & $\begin{array}{l}\text { Verify, if the } \\
\text { communities have a well } \\
\text { primary health care clinic }\end{array}$ \\
\hline $\begin{array}{l}\text { political } \\
\text { position }\end{array}$ & $\begin{array}{l}\text { Each community } \\
\text { have to be consider } \\
\text { in time of political } \\
\text { sharing }\end{array}$ & $\begin{array}{l}\text { Unequal or inappropriate } \\
\text { distribution of political } \\
\text { position may instigate } \\
\text { dispute, grudge in the } \\
\text { heart of individual which } \\
\text { can also result to } \\
\text { community crisis }\end{array}$ & $\begin{array}{l}\text { Proper distribution of } \\
\text { political position should } \\
\text { be done with a highly } \\
\text { consideration of the } \\
\text { majority, minority, tribally } \\
\text { and religiously. }\end{array}$ & $\begin{array}{l}\text { Verify, Has there be } \\
\text { properly distribution of } \\
\text { political position }\end{array}$ \\
\hline
\end{tabular}




\begin{tabular}{|c|c|c|c|c|}
\hline $\begin{array}{l}\text { Social amenity } \\
\text { and } \\
\text { infrastructure }\end{array}$ & $\begin{array}{l}\text { There should be } \\
\text { infrastructure to } \\
\text { communities }\end{array}$ & $\begin{array}{l}\text { Absent of infrastructure } \\
\text { deny community of public } \\
\text { benefit, private sector } \\
\text { from inventing, as a result } \\
\text { of poor road network, } \\
\text { rather they are expose to } \\
\text { disease such as cholera, } \\
\text { typhoid, riches, stomach } \\
\text { pains as a result of dirty } \\
\text { water. }\end{array}$ & $\begin{array}{l}\text { There should be road, } \\
\text { water supply and } \\
\text { electricity to allow stable } \\
\text { economic activities }\end{array}$ & $\begin{array}{l}\text { It should be verify } \\
\text { whether the communities } \\
\text { have access to road, pipe } \\
\text { water, and electricity }\end{array}$ \\
\hline Dialogue & $\begin{array}{l}\text { A justified } \\
\text { dialogue on issue } \\
\text { that seem to be } \\
\text { complicat-ed }\end{array}$ & $\begin{array}{l}\text { This involve disrespect } \\
\text { and an attitude not ready } \\
\text { to listen to one talk, also } \\
\text { not ready to address } \\
\text { diversity and division } \\
\text { among tribes and } \\
\text { religious }\end{array}$ & $\begin{array}{l}\text { There should be dialogue } \\
\text { among the community on } \\
\text { dispute issues through } \\
\text { their chief head }\end{array}$ & $\begin{array}{l}\text { It should be verify that } \\
\text { did they enter dialogue in } \\
\text { times of dispute. }\end{array}$ \\
\hline Law & $\begin{array}{l}\text { There should be } \\
\text { law guiding } \\
\text { communit-ies. }\end{array}$ & $\begin{array}{l}\text { Ineffectiveness of law give } \\
\text { rise to sexual abuse, drug } \\
\text { abuse especially } \\
\text { marijuana, stealing, } \\
\text { killing, fighting and so } \\
\text { many form of criminal act } \\
\text { that result in insecurity of } \\
\text { life and properties }\end{array}$ & $\begin{array}{l}\text { There should be law that } \\
\text { conveys social changes } \\
\text { and shapes various form } \\
\text { of life style. }\end{array}$ & $\begin{array}{l}\text { Find out that the } \\
\text { communities have law } \\
\text { guiding them. }\end{array}$ \\
\hline
\end{tabular}




\begin{tabular}{|c|c|c|c|c|c|}
\hline $\begin{array}{l}\text { Law reform } \\
\text { agencies }\end{array}$ & $\begin{array}{l}\text { Communities } \\
\text { should regulate law } \\
\text { guiding them }\end{array}$ & $\begin{array}{l}\text { Failure in reforming the } \\
\text { law will result to } \\
\text { inadequate application of } \\
\text { the existent law in time } \\
\text { run as changes will be } \\
\text { taking place in the } \\
\text { communities as a result it } \\
\text { may fail in imposing a } \\
\text { appropriate punishment to } \\
\text { some offences which can } \\
\text { cause conflict among the } \\
\text { individual, groups, tribes, } \\
\text { and religious. }\end{array}$ & $\begin{array}{l}\text { Communities should have } \\
\text { their law reform agencies } \\
\text { with the responsibility of } \\
\text { monitoring the operation } \\
\text { of the law and proposing } \\
\text { and reforming of the law } \\
\text { as changes occurs in the } \\
\text { communities. }\end{array}$ & $\begin{array}{l}\text { The communities should } \\
\text { be verify to know if they } \\
\text { have law reform } \\
\text { agencies. }\end{array}$ & \\
\hline Police station & $\begin{array}{l}\text { There should be a } \\
\text { police station in } \\
\text { each community }\end{array}$ & $\begin{array}{l}\text { The absent of police } \\
\text { station will result to break } \\
\text { down of rules, less } \\
\text { privilege will be deny their } \\
\text { right, and dehumanize } \\
\text { people. }\end{array}$ & $\begin{array}{l}\text { Police station should be } \\
\text { site in each community to } \\
\text { avert the breakdown of } \\
\text { rules and regulation, to } \\
\text { protect and defend the less } \\
\text { privilege there right. }\end{array}$ & $\begin{array}{l}\text { It should be verified that } \\
\text { each community have a } \\
\text { police station }\end{array}$ & \\
\hline Schools & $\begin{array}{l}\text { Each community } \\
\text { should have } \\
\text { Nursery, Primary } \\
\text { and Secondary } \\
\text { schools }\end{array}$ & $\begin{array}{l}\text { Lack of schools in a } \\
\text { community or society will } \\
\text { give ways for illiteracy, } \\
\text { restricting people from } \\
\text { social life and adopting the } \\
\text { primitive and cultural way } \\
\text { norms that hinders } \\
\text { civilization as a result will } \\
\text { under develop the } \\
\text { community, society and } \\
\text { environment and at times } \\
\text { may result to violence due } \\
\text { to miss understanding that } \\
\text { can easily occur in there } \\
\text { mist }\end{array}$ & $\begin{array}{l}\text { Each community should } \\
\text { be provided with nursery, } \\
\text { primary and secondary } \\
\text { schools to eliminate } \\
\text { illiteracy from the } \\
\text { communities }\end{array}$ & $\begin{array}{l}\text { It should be verify that } \\
\text { each community have } \\
\text { nursery, primary, } \\
\text { secondary schools and a } \\
\text { well equip, quality and } \\
\text { quite a number of staff. }\end{array}$ & $\mathrm{s}$ \\
\hline
\end{tabular}




\begin{tabular}{|c|c|c|c|c|c|c|c|}
\hline S/No & Process & Inhere & isk & & Residua & Risk & \\
\hline & & High (H) & Medium (M) & Low (L) & High $(\mathbf{H})$ & Medium (M) & Low (L) \\
\hline 1 & Employment & & & & & & \\
\hline 2 & Education & & & & & & \\
\hline 3 & Political position & & & & & & \\
\hline 4 & $\begin{array}{l}\text { Social Amenities } \\
\text { and infrastructure }\end{array}$ & & & & & & \\
\hline 5 & Police Station & & & & & & \\
\hline 6 & Law & & & & & & \\
\hline 7 & Dialogue & & & & & & \\
\hline 8 & $\begin{array}{l}\text { Law reform } \\
\text { agency }\end{array}$ & & & & & & \\
\hline 9 & $\begin{array}{l}\text { Primary Health } \\
\text { care }\end{array}$ & & & & & & \\
\hline 10 & Schools & & & & & & \\
\hline & & & & & & & \\
\hline
\end{tabular}




\begin{tabular}{|l|l|l|}
\hline $\begin{array}{l}\text { Control self Risk Assessment } \\
\text { (CSRA) }\end{array}$ & $\begin{array}{l}\text { Risk before assessing the community } \\
\text { (Inherent) } \mathrm{X}_{1}\end{array}$ & $\begin{array}{l}\text { Risk after assessing the community } \\
\text { (Residual) } \mathrm{X}_{2}\end{array}$ \\
\hline $\begin{array}{l}\text { Number of high Risk } \\
\text { (Unsatisfactory Risk) }\end{array}$ & & \\
\hline $\begin{array}{l}\text { Number of medium } \\
\text { (Needing improvement) }\end{array}$ & & \\
\hline $\begin{array}{l}\text { Number of low Risk } \\
\text { (which is satisfactory) }\end{array}$ & & \\
\hline
\end{tabular}

This is the analysis of one the community

The test for KUBA HAMLET community

\begin{tabular}{|l|c|c|}
\hline $\begin{array}{l}\text { Control self Risk } \\
\text { Assessment } \\
\text { (CSRA) }\end{array}$ & $\begin{array}{l}\text { Risk before assessing the } \\
\text { community (Inherent) } X_{1}\end{array}$ & $\begin{array}{l}\text { Risk after assessing the } \\
\text { community (Residual) } X_{2}\end{array}$ \\
\hline $\begin{array}{l}\text { Number of high Risk } \\
\text { (Unsatisfactory Risk) }\end{array}$ & 5 & 4 \\
\hline $\begin{array}{l}\text { Number of medium } \\
\text { (Needing improvement) }\end{array}$ & 2 & 4 \\
\hline
\end{tabular}




\begin{tabular}{|l|l|c|}
\hline $\begin{array}{l}\text { Number of low Risk } \\
\text { (which is satisfactory) }\end{array}$ & 3 & 2 \\
\hline
\end{tabular}

Number of satisfactory Risk after assessing is 2

Number of needing improvement Risk after assessing is 4

Number of unsatisfactory Risk after assessing is 4

Hence to calculate the value of risk present in this community I use the simplex method of Linear Programming.

Let $\mathbf{x}_{1}$ and $\mathbf{x}_{2}$ represent the number of inherent risk and residual risk given by;

Min: $4 \mathrm{X}_{1}+4 \mathrm{X}_{2}$ Objective function

Subject to the constraints

To get the solution variables, we take the percentage value of each process.

$$
\begin{aligned}
& 5 / 4 \times 100=125 \\
& 2 / 4 \times 100=50 \\
& 3 / 2 \times 100=150
\end{aligned}
$$

To proceed, let $\mathrm{x}_{1}$ and $\mathrm{x}_{2}$ represent the number of inherent risk and residual risk given by;

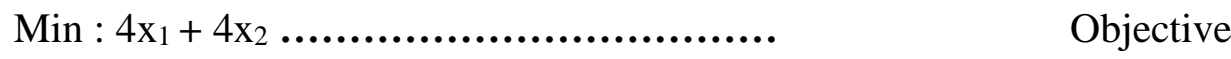

$$
\begin{aligned}
& 5 \mathrm{x}_{1}+4 \mathrm{x}_{2} \geq 125 \\
& 2 \mathrm{x}_{1}+4 \mathrm{x}_{2} \geq 50 \\
& 3 \mathrm{x}_{1}+2 \mathbf{x}_{2} \geq 150
\end{aligned}
$$


Where $\mathrm{x}_{1} \geq 0$ and $\mathrm{x}_{2} \geq 0$

\section{Solution}

We augment the matrix corresponding to the minimization problem above

$$
\begin{aligned}
& 5 \quad 4: 125 \\
& 24: 50 \\
& 3 \text { 2: } 150 \\
& \begin{array}{ccc}
\ldots & 4 & \\
4 & & 0
\end{array}
\end{aligned}
$$

\begin{tabular}{|c|c|c|}
\hline 5 & 2 & 3 \\
\hline 4 & 4 & 2 \\
\hline 125 & 50 & 150 \\
\hline
\end{tabular}

Next, we form the transpose of this matrix by interchanging its rows and columns.

thus our dual maximization problem will be

$$
\begin{array}{r}
\text { Max : } 125 \mathrm{x}_{1}+50 \mathrm{x}_{2}+150 \mathrm{x}_{3} \quad \text { Dual objective function } \\
5 \mathrm{x}_{1}+2 \mathrm{x}_{2}+3 \mathrm{x}_{3} \leq 4 \\
4 \mathrm{x}_{1}+2 \mathrm{x}_{2}+2 \mathrm{x}_{3} \leq 4
\end{array}
$$

Where $x_{1} \geq 0, \quad x_{2} \geq 0$, and $x_{3} \geq 0$. 


\section{Solution}

Multiply the dual objective function by -1

$$
\begin{array}{r}
\operatorname{Max}:-125 x_{1}-50 x_{2}-150 x_{3} \\
5 x_{1}+2 x_{2}+3 x_{3} \leq 4 \\
4 x_{1}+2 x_{2}+2 x_{3} \leq 4
\end{array}
$$

\begin{tabular}{|c|c|c|c|c|c|c|}
\hline \multirow[t]{2}{*}{$\mathrm{S}_{1}$} & 5 & 2 & 3 & 1 & 0 & 4 \\
\hline & 4 & 2 & 2 & 0 & 1 & 4 \\
\hline
\end{tabular}

$\begin{array}{lllllll}\text { Bas. variable } & \mathrm{x}_{1} & \mathrm{x}_{2} & \mathrm{x}_{3} & \mathrm{~s}_{1} & \mathrm{~s}_{2} & \mathrm{~b}\end{array}$

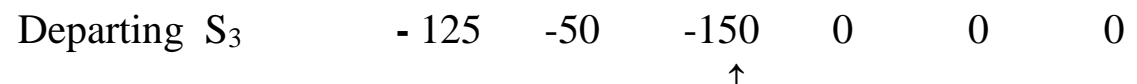

New Row 1

$$
\begin{aligned}
& \mathrm{OR}_{1} / 3=5 / 3 \quad 2 / 3 \quad 3 / 3 \quad 1 / 3 \quad 0 / 3 \quad 4 / 3 \\
& \mathrm{NR} 1=5 / 3 \quad 2 / 3 \quad 1 \quad 1 / 3 \quad 0 \quad 4 / 3
\end{aligned}
$$

$\mathrm{NR}_{2}=\mathrm{OR}_{2}-2 \mathrm{NR}_{1}$

$\begin{array}{llllll}4 & 4 & 2 & 0 & 1 & 4\end{array}$




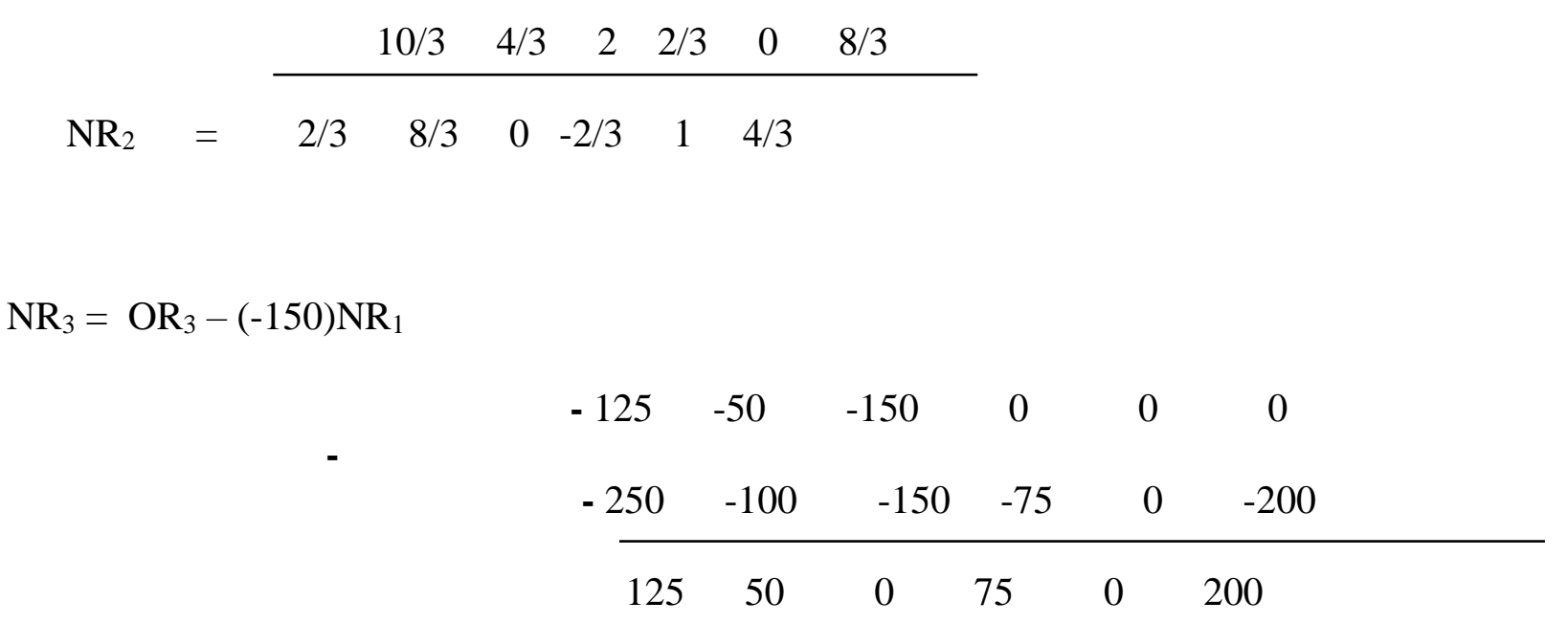

\begin{tabular}{|c|c|c|c|c|c|c|c|}
\hline Basic va & e $x_{1}$ & $x_{2}$ & $x_{3}$ & $\mathrm{~s}_{1}$ & $\mathrm{~s}_{2}$ & b & \\
\hline $\mathrm{X}_{3}$ & $5 / 3$ & $2 / 3$ & $1 / 3$ & $1 / 3$ & 0 & $4 / 3$ & \\
\hline $\mathrm{s}_{2}$ & $2 / 3$ & $8 / 3$ & 0 & $-2 / 3$ & 1 & $4 / 3$ & \\
\hline \multicolumn{2}{|c|}{$S_{3}$} & 125 & 50 & 0 & $\begin{array}{c}50 \\
\uparrow \\
x_{1}\end{array}$ & $\begin{array}{l}0 \\
\uparrow \\
\mathrm{x}_{2}\end{array}$ & 200 \\
\hline
\end{tabular}

\section{Interpretation}

From this final tableau, we see the present value of Risk in this community from Row s3 to be 200 .

To verify our minimization objective function of Inherent and Residual Risk

$$
\text { Min : } 4 \mathrm{x}_{1}+4 \mathrm{x}_{2}
$$


Substitute the value of $\mathbf{s}_{\mathbf{1}}$ and $\mathbf{s} \mathbf{1}$ from the final tableau

Min : $4 \mathrm{x}_{1}+4 \mathrm{x}_{2}$

$4(50)+4(0)$

$200+0$

200 